\title{
5.2
}

\section{The core executive and government}

Patrick Dunleavy looks at how well the dominant centre of power in the British state operates - spanning the Prime Minister, Cabinet, Cabinet committees, ministers and critical central departments. How accountable and responsive to Parliament and the public is this 'core executive'? And how effective are these key centres of decision-making and the rest of Whitehall government, in making policy? Do they consistently serve UK citizens' interests?

\section{What does democracy require of the core executive, along with wider central government?}

The core executive should provide clear unification of public policies across government, so that the UK state operates as an effective whole, and citizens and civil society can better understand decision-making.

The core executive especially, and central government more widely, should continuously protect the welfare and security of UK citizens and organisations. Government should provide a stable and predictable context in which citizens can plan their lives and enterprises, and civil society can conduct their activities with reasonable assurance about future government policies.

$\downarrow$ Both strategic decision-making within the core executive, and more routine policymaking across Whitehall, should foster careful deliberation to establish the most inclusive possible view of the 'public interest'. Effective policy should maximise benefits and minimise costs and risks for UK citizens and stakeholders.

$\downarrow$ Checks and balances are needed within the core executive to guard against the formulation of ill-advised policies through 'groupthink' or the abuse of power by one or a few powerful decision-makers. Where 'policy fiascos' occur the core executive must demonstrate a concern for lesson-drawing and future improvement.

t The core executive and government should operate fully within the law, and ministers should be effectively scrutinised by and politically accountable to Parliament. Ministers and departments/agencies must also be legally accountable to the courts for their conduct and policy decisions. 
$\downarrow$ Policy-making and implementation should be as transparent as possible, while recognising that some special core executive matters may need to be kept secret, for a time. Parliament should always be truthfully informed of decisions and policy plans as early as possible, and House of Commons debates and scrutiny should influence what gets done.

4 Policy development should ideally distribute risks to those social interests best able to insure against them (that is, at lowest cost). Consultation arrangements should ensure that a full range of stakeholders can be and are easily and effectively involved. Freedom of information provisions should be extensive and implemented in committed ways.

The executive is the part of the state that makes policies and gets things done, with ministers answering in public directly to Parliament, and via elections to voters. At UK national level, and across all of England, the executive consists of ministerial departments and big agencies headquartered in Whitehall, each making policy predominantly in a single policy area. This centre also funds and guides other implementing parts of the state such as the NHS, local authorities, police services and a wide range of quasi-government agencies and 'non-departmental public bodies' (NDPBs).

Within the centre, the 'core executive' is the functional apex (or the brains/heart) of state decision-making. In any country it is the set of institutions that unifies the polity and determines the most important or strategic policies. In the UK the 'core executive' includes the Prime Minister, who appoints the Cabinet, plus Cabinet committees, key ministers in central Whitehall departments, and some top officials in the same departments - especially the Treasury, Cabinet Office, 10 Downing Street staffs, the Foreign Office, the Ministry of Defence, the intelligence services and the Bank of England. The core executive especially makes 'war and peace' decisions, shaping the UK's external relations and commitments, homeland security and immigration, strategic economic policies (like austerity, national debt and deficit financing), and the direction of broad policy agendas from the top (like Brexit). Parts of the core executive's activities are shrouded in secrecy, and much that gets done remains confidential at the time.

\section{Recent developments}

In July 2018 Theresa May summoned her Cabinet to the Prime Minister's country home at Chequers and briefed them on the negotiating position for UK withdrawal from the EU. After months of wrangling and disagreements between Leave and Remainer ministers, and between Whitehall departments, the White Paper she required them to vote to accept had been drawn up by staff in the Cabinet Office under her direction (chiefly by Oliver Robbins) and discarded a quite different paper that the Department for Exiting the EU (DExEU) had been working on for months. Faced with an ultimatum the Cabinet voted to agree, but two days later Boris Johnson (the Foreign Secretary) and David Davis (the DExEU Secretary of State) and a strongly Brexiteer junior minister at DExEU resigned. Five other Leave Cabinet ministers, who had concerted positions with Johnson and Davis the night before 
the Chequers showdown, decided to stay on. A few days later, the government took the Chequers deal to the hung Commons, but had to back down and accept four amendments proposed by Tory Brexiteer MPs from the European Research Group. The amended proposals passed the Commons by margins as low as three votes, as Conservative Remainers defied their party's whip.

This incident marked one climactic peak (there will likely be others) in the conflictual executive politics between Leaver, pragmatists and Remainers that marked the May government from the outset, and intensified as the UK's withdrawal negotiations with the EU neared critical decision points. Previous UK core executive conflicts were mainly 'dyadic', two-way struggles between a Prime Minister and a rival or successor in one of the top four Cabinet roles - Chancellor, Foreign Secretary, Home Secretary and sometimes Defence Minister (see 'weaknesses' in the SWOT analysis below). The transition to triadic or three-way conflicts reflects the strong divisions within the Conservative Party (see Chapter 3.1). It was made worse by May's 'closed decision-making' style, and her habit of briefing symmetrically against her leading colleagues in 2016-17 - for example, in the run-up to the mishandled 2017 election May's staff clearly signalled the press and her MPs that Philip Hammond (Chancellor) and Johnson would be dumped in her new government.

In a weakened position after losing her majority, May was unable to act on either of these ambitions. Even her new appointments, like the not-very-well-known Gavin Williamson as Defence Secretary, began using resignation threats overtly in the press to seek bigger budgets. The government abandoned practically all the controversial components of the damaging Tory manifesto, and May called for inter-party co-operation. But the Prime Minister was living on borrowed time and her administration could not seem to get a modus operandi for liaising more constructively on Brexit with Labour or the devolved governments in Scotland and Wales, whose legislative consent will probably be needed.

However, one root of May's collapsing authority can be traced back to David Cameron's position after winning a narrow Conservative majority in the 2015 general election. The result seemed to signal the resumption of 'normal service' for peacetime government in Britain. The apparatus of the five-year Conservative-Liberal Democrat coalition government was swept into the dustbin. The post of Deputy PM, which had been held by Nick Clegg, returned to the cupboard of history. And the inner co-ordination committee of four (Cameron, George Osborne at the Treasury, Clegg and Danny Alexander, Chief Secretary at the Treasury) that had kept the coalition operating smoothly for so long, was scrapped. Cameron kept Whitehall's department structure largely unchanged, as he had under the coalition, and ruled mainly with Osborne. Boris Johnson (a possible leadership succession contender) was brought into the Cabinet in a minor role.

Cameron had alighted on the pledge of an in/out referendum in early 2013 as a tool to keep the dissidence of the Tory right's MPs under control in the short term. But as the pledge hardened and UKIP boomed in 2014, Cameron began to make a drip-drip of extra concessions to his far-right ministers and MPs. Jockeying between the relatively few Cabinet Eurosceptics and the strongly pro-EU 'Cameroons' became more vigorous as the Prime Minister moved to deliver on his election pledge to hold an in/out referendum on the European Union. Buoyed up by their experience of (narrowly) winning the Scottish 
independence referendum with a 'big fear' campaign warning of disastrous consequences, Cameron and Osborne re-ran almost the same playbook and for a long time seemed to be winning. Yet Eurosceptic ministers were allowed to campaign for Leave, and a significant minority did so (while May and some others were 'apathetic Remainers'). This suspension of collective Cabinet responsibility during the referendum campaign meant that Eurosceptic ministers need not resign their posts, despite publicly contradicting everything that the Prime Minister and Chancellor were saying. In the end it was the committed Eurosceptic Michael Gove and the initially more diffident late-convert Johnson whose campaigning caused the 'doom and gloom' Brexit campaign to be lost on 23 June, 2016. Cameron resigned the next morning.

From the ensuing chaos of an aborted Tory leadership contest (in which Gove and Johnson both imploded early on), Theresa May emerged as winner, becoming Prime Minister after a two-week interregnum. She initially signalled a pattern of strong central control from Downing Street by keeping only three out of 24 Cabinet ministers in the same roles as before, promoting Johnson to the Foreign Office, and exiling Gove (for a year) and Osborne (for good). She created two new Whitehall departments for the major Eurosceptics David Davis (DExEU) and Liam Fox (International Trade) to run key Brexit functions. A very centralist 10 Downing Street operation was headed by two powerful staffers who had followed May from the Home Office (Nick Timothy and Fiona Hill). In a speech at Lancaster House, May outlined a 'hard Brexit' stance, which toughened up the referendum vote decision into a commitment to re-control all immigration and exit fairly completely from all EU institutions and arrangements.

This regime collapsed within a year, after May reversed her previous public pledges and called a general election (which Jeremy Corbyn's Labour agreed to under the terms of the Fixed-term Parliaments Act). What seemed like a smart move for May, and a suicidal one by Corbyn, turned out to be exactly the opposite, with May losing her majority of MPs in June 2017. The government clung to power only by negotiating a 'confidence and supply' agreement with the ten MPs from the Northern Ireland Democratic Unionist Party (DUP), at a reputed minimum cost of a £1bn 'bung' for public spending there. May’s closest advisors, Timothy and Hill, were blamed for the disastrous Tory manifesto and hounded from office by Tory newspapers and MPs. A more outwardly 'consensual' regime for running the Conservative parliamentary party was put in place, with a quasi-Deputy PM the more accommodating Damian Green, but he lasted only a year before resigning over a porn scandal. 


\section{Strengths, Weaknesses, Opportunities, Threats (SWOT) analysis}

\section{Current strengths}

British government before 2010 was normally strongly unified, with clear Prime Ministerial and Cabinet control, strong ministerial roles within Whitehall departments, single-party governments, and relatively clear and distinct strategic policy stances. All of these features were briefly visible again in 2015-16, and some were present in 2016-17 - but not in the other six years since 2010 under hung parliaments.

Cabinet government and the extended Cabinet committee system provide key checks on the power of Prime Ministers and their 10 Downing Street office. They foster greater deliberation before policy commitments are made, and a balanced approach, with the different departments ideally representing diverse stakeholders' interests and wider public reactions.

Decisions within the core executive are normally made on far more than a simple majority rule (51\% agreement). Instead an initial search looks for a high level of consensus across ministers/ departments. This may give way to deciding on a lesser but still 'large majority’ (for example, 60\% agreement) basis, especially in crises or situations where the status quo is worsening.

\section{Current weaknesses}

The Prime Minister's 'three As' powers are extensive. She appoints Cabinet ministers, allocates their portfolios and assigns policy issues across departments. Theoretically she can so arrange ministers' policy trade-offs that they will perfectly implement the premier's preferences. In 'normal' times, most ministers are highly dependent on the Prime Minister's patronage and access for influence.

In pursuit of purely political advantages, Prime Ministers have often re-jigged ministerial roles by pushing through reorganisations 'making and breaking Whitehall departments' (see below). This administrative churning is costly, short-termist and disruptive, reaching a peak under the Blair and Brown governments. A near-moratorium on reorganisations followed under Cameron's premiership (2010-16), only to be succeeded by drastic changes and a wholesale reshuffle of ministers under May in June 2016.

Cabinet decision-making no longer operates in any effectively collegial manner. Prime Ministers control the routing of issues through committees and can bypass them via 'bilaterals' and 'sofa government'. For example, even the weakened Theresa May was able to re-centralise power from her DExEU Secretary, creating a Cabinet Office unit that in the end wrote a completely different White Paper by summer 2018 from the one the department had been working on. In 'normal times' strong integration of government communications also enforces complete solidarity across all ministers, without any guarantee of participation in decisions. Ministers mainly fight back by 'adversarial leaking', which is in turn routinely denied. 


\section{Current strengths}

Because of these processes, the principle of 'collective responsibility' binds Cabinet ministers to publicly back every agreed government policy, and not to talk 'off their brief'. Wider ministerial solidarity also requires all junior ministers to follow the government line (for example, resigning if they do not vote the government line in the Commons). This convention held even over the July 2018 three-way Chequers agreement battle.

\section{Current weaknesses}

The UK still has a 'fastest law in the West' syndrome, with the fewest checks and balances of any liberal democracy on the Prime Minister or the core executive especially in one-party governments with secure Commons majorities. But even May made her own EU negotiating position far weaker by triggering Article 50 to leave with only a two-year period to go. Decisions can be (and often are) made 'lightly or inadvisedly'. Ministers can simply escape any unfavourable consequences of bad policies through party loyalties making them invulnerable in the legislature.

Policy-making can take place swiftly when needed. Whitehall's resilience in crisishandling and its capacity to respond to demanding contingencies are generally high.
Recurring 'groupthink' episodes have produced major 'policy disasters' - most recently the UK's involvement on false grounds in the 2003 invasion of Iraq; the disastrous 2011 armed intervention with France in Libya; and Theresa May's calling of an early general election in 2017. Arguably the UK is more prone to major 'policy disasters' than other liberal democracies (see below).

There is little evidence of much substantial policy-learning capacity within the core executive. All British Prime Ministers back to Stanley Baldwin (in 1935) have been forced to retire by election defeats, coups against them within their own parties, or illness. None has retired to acclaim as a successful leader.

'Policy fiascos' occur when Prime Ministers and governments choose to ignore credible warnings of foreseeable policy disasters. Even on relatively mundane legislation, ministers and departments often choose to ignore or override the feedback received.

Ministerial decision-making operates in a climate of pervasive secrecy (still enforced by the Official Secrets Act). Ministers often withhold information from Parliament, reject FOI requests on questionable grounds, and manipulate the flows of information to their own advantage. They incur only small costs when found out, unless a scandal takes root.
All ministers sit in Parliament and are directly and individually accountable there for their actions. The Freedom of Information (FOI) Act secures public transparency. Modern media, interest group and social media scrutiny is intense, rapid and fine-grained. 


\section{Current strengths}

\section{Current weaknesses}

Long-running dyadic power conflicts have occurred between Prime Ministers and key ministerial colleagues (especially the Chancellor or Foreign Secretary). These have been the main exceptions to Prime Ministerial dominance. Here a powerful minister (often an alternate leadership contender) can amass enough influence with colleagues to exercise a 'blocking veto' on what the Prime Minister wants to happen in key policy areas, usually those related to their brief. Under large majority rules this frustrates implementation of the Prime Minister's preferred policy. It either results in inaction, or on extra time being spent to achieve a bargained compromise between the Prime Minister and the vetoing minister. Notable cases include Thatcher-Lawson/Howe conflicts on EU policy (1985-90), the Blair-Brown public spending conflicts (1997-2007), Cameron-Clegg tussles (2010-15), and post-Brexit referendum disagreements within the May governments (2016-17).

\section{Future opportunities}

Over the 43 years of the UK's membership of the EU, Westminster ministers lost power to Brussels. Perhaps unconsciously British elites compensated by focusing more and more attention on 'micro-managing' the public services still within their control in the UK and in England and being implemented by regional or local bodies. This strong centralisation dynamic was checked only by some 'organic' devolution (see Chapter 5.6). Now that the UK is leaving the EU, many lost central government competences need to be re-built to 'take back control' of trade and economic policy. A post-Brexit re-focusing may encourage ministers and Whitehall to ease up on trying to fine-control public services that are best run at regional or local levels. At the least the burden of Brexitrelated laws will squeeze opportunities for other kinds of domestic legislation.

\section{Future threats}

The Brexit process will remove a whole set of checks and balances on UK decision-making that have operated for 43 years at EU level in Brussels. These mainly enhanced stability and a long-run perspective in policy-making. As a result, the organisational culture of more short-termist and failure-prone modes of decision-making (that prevail in defence, foreign policy and welfare state management) may reinvade key parts of UK policy, especially in economic regulation, innovation and environmental policies. 


\section{Future opportunities}

The government accepted motions backed by a majority of MPs requiring a Commons sifting committee to scrutinise the Brexitrelated statutory instruments. The efficacy of this arrangement versus the information advantages of ministers and Whitehall remains to be established.

\section{Future threats}

Working through the Brexit process will take many years and entail one of the largest and most demanding shifts in public policy-making of the last three decades. Many observers doubt that ministers and Whitehall will be able to respond well to this challenge.

As originally drafted, the May government relied heavily on 'Henry VIII' clauses in Brexit legislation, which would allow ministers to vary inherited EU laws using some 900 hardto-scrutinise statutory instruments instead of new legislation in Parliament. This is now altered but there remain concerns that new 'sifting' measures remain too weak.

In the 2016-17 period there were disturbing signs of another eminently foreseeable policy fiasco emerging through Conservative ministers' partisan stress on following a 'hard Brexit' strategy, whose economic costs could be high.

\section{Making and breaking Whitehall departments}

One of a Prime Minister's most potent uses of Crown prerogative powers involves their unilateral control over the structure of Whitehall departments. Prime Ministers can scrap, merge, de-merge and reorganise ministries at will, often creating new ones to reflect their priorities or to respond to external changes. Figure 1 below shows that in the postwar period there were two periods of rapid reorganisation, in the late 1960s/early 1970s, and under the modernising Blair and Brown 'New Labour' governments. Most redesigns occur in the first two years of each premiership. Research shows that political priorities in Cabinet-making dominated administrative ones in most of the reorganisations - many of which were done by Prime Ministers in a great rush and with little or no planning. The past level of churn in Whitehall structures made the UK exceptional amongst OECD countries, and stood out even when compared with other 'Westminster system' countries. 
Figure 1: Major reorganisations of Whitehall departments by Prime Ministers, 1950 to 2018

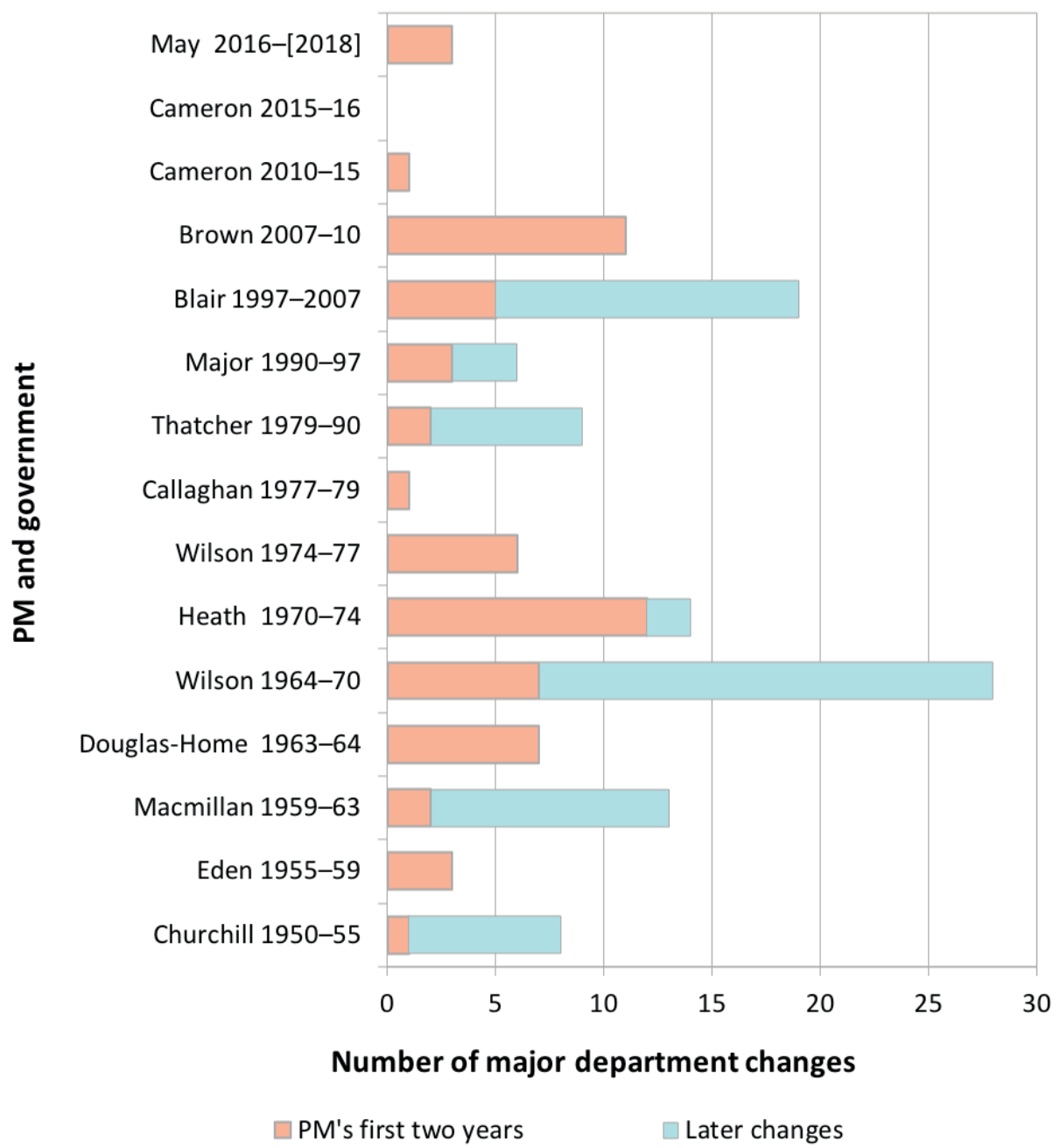

Source: Up to 2010: White and Dunleavy, 2010, Figure 8, p. 20. From mid-2010 on: Institute for Government, Whitehall Monitor series.

In 2010, David Cameron decided not to reorganise Whitehall, a course which he saw as a costly distraction when the UK's priority was cutting public sector deficits. He contented himself with abolishing a recent Labour-created department (called DIUS). (His Tory Secretary of State for Health, however, pushed through a costly and pointless 'reform' of NHS governance'.) Throughout Cameron's five years running a coalition government he could not act alone, since ministerial appointments formed key parts of the coalition agreement, although he reshuffled Tory ministers a little. In 2016, he continued this stance, so that the UK seemed to be acting more like a standard OECD country with stable department structures. 
All this changed under Theresa May, who created two new ministries: DExEU, to manage the Europe Union withdrawal process; and DIT, the Department for International Trade, to resume the trade deals role previously assigned to Brussels, and in which the UK lacked all expertise. May also reconfigured two existing departments in major ways, abolishing the previous Department for Energy and Climate Change and transferring most of its functions to BEIS, the department for Business, Energy and Industrial Strategy. In line with previous yo-yo changes over the decades, the responsibilities for skills plus universities and research moved back to the Education Department. Figure 2 shows that these changes plus the Brexit preparations created some substantial boosts to many policy departments' staff; but the biggest employers (HMRC, DWP and MoD) remained stable. DExEU is almost designed to not last too long, although DIT look as if it may endure. Instead of DExEU, an alternative strategy would have been to create a neutral Cabinet Office unit under Prime Ministerial authority to run Brexit negotiations. Effectively May belatedly followed this course from autumn 2017, sucking much of the momentum out of DExEU and helping trigger David Davis' resignation nine months later.

Figure 2: Changes in Whitehall departments' staffing levels, 2016-18

\author{
International Trade \\ Education \\ Department for Exiting the EU \\ Cabinet Office \\ Environment, Food and Rural Affairs \\ Transport \\ International Development \\ Culture Media and Sport
}

Business, Enterprise, Innovation and Skills

HM Revenue and Customs

Home Office

Whole Civil Service

HM Treasury

Ministry of Defence

Work and Pensions

Ministry of Justice

Foreign Office

Communities and Local Government

Health

$\square$ Increase since Q2 2016

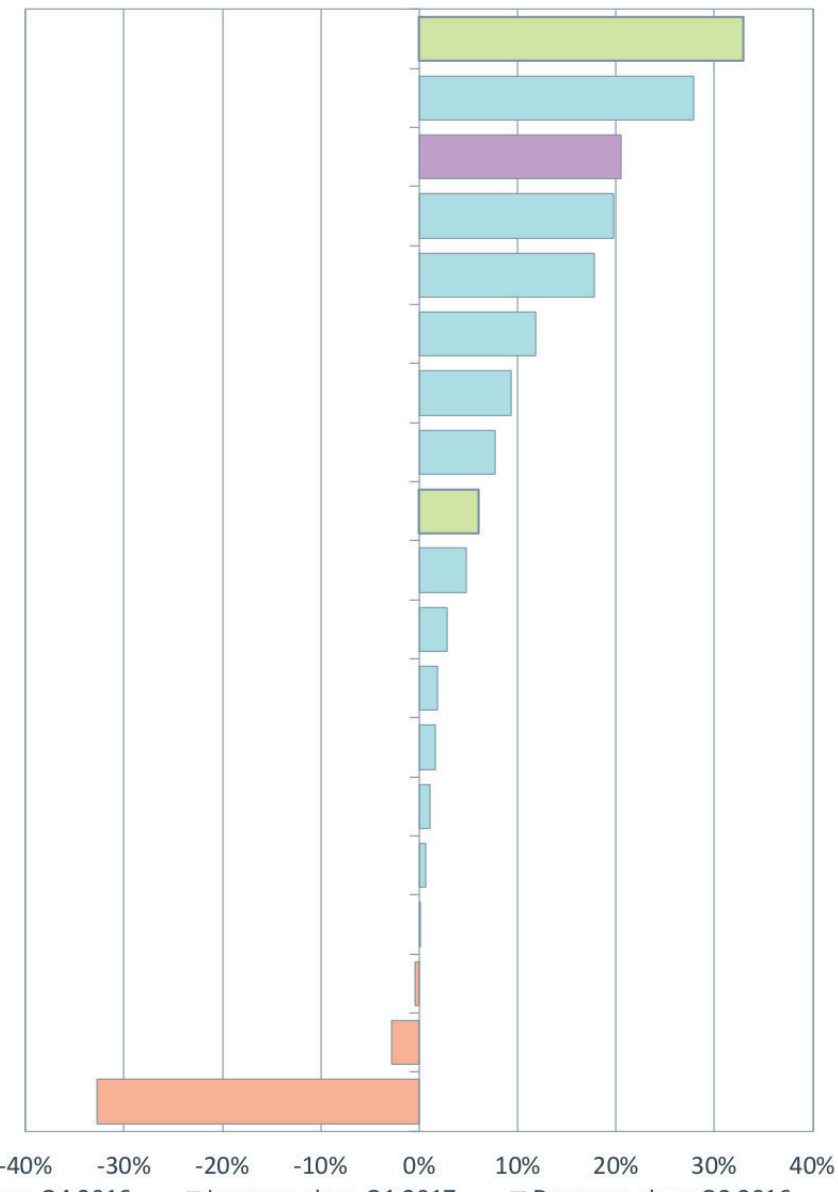

口Increase since Q4 2016
Source: Institute for Government, Whitehall Monitor 2018, Figure 2.3.

Notes: Some DExEU staff are on loan from FCO and other departments, and so may be counted twice. 


\section{The Cabinet committee system}

Below the large, 23-member Cabinet, the Westminster system has traditionally operated one of the most elaborate committee systems of any liberal democracy. All relevant Cabinet departments sit on related committees, but in the past there were many more committees, arranged in a complex hierarchy. 'Prime Ministers decide how to organise [committees], who to appoint to them, and how actively they are involved in them'. However, Nicholas Allen and Nora Siklodi demonstrated that:

'May has streamlined the committee system she inherited from David Cameron. Instead of ten committees, ten subcommittees and eleven "implementation taskforces" (bodies introduced in 2015 to drive forward the government's "most important crosscutting priorities") [31 major bodies in all], there are now just five committees, nine subcommittees handling regular business, and seven taskforces [21 major bodies]'. [Our emphasis.]

By November 2017, May's tuning of the government machine to yield her kind of administration, plus the huge load increasingly associated with the Brexit negotiations (which shut down a lot of legislation and activity on other issues), produced the Cabinet committee structure shown in Figure 3, perhaps the smallest in living memory - with just 16 policy committees and sub-committees and only five taskforces. Almost half of these new bodies were chaired by the Prime Minister herself (as shown), including all the main substantive committees, a historically unusual level of centralisation.

Critics argue that May favours a 'closed decision-making' style, with power concentrated in her hands, plus 10 Downing Street and a few favoured delegates. The Leader of the Commons chaired the only other full committee, scheduling legislative business. The Chancellor and Home Secretary chaired two sub-committees each, and the Business Secretary and Party Chairman chaired one. Three other ministers chaired one or two taskforces, which on past form may meet irregularly or infrequently. Running the committee system and keeping track of what departments have committed to do, and of their progress in meeting targets, is the Cabinet Office secretariat. It provides a strong administrative core, ensuring that decisions and commitments are carefully recorded and then chased up.

Using a counting and weighting system applied to committees in all UK governments since 1992, we can calculate the 'positional power' of ministers in terms of their places, and their share of the total. Figure 4 shows that in summer 2016 the new bigger committees and some sub-committees gave a place to almost everyone on almost everything, so that the Prime Minister's share of positional power was less than $11 \%$. Comparing earlier research shows that May's number was greater than John Major's 7.6\% score in 2001, but down on Tony Blair's score of $14.9 \%$ in 1997. 
Figure 3: Theresa May's Cabinet committee structure in November 2017

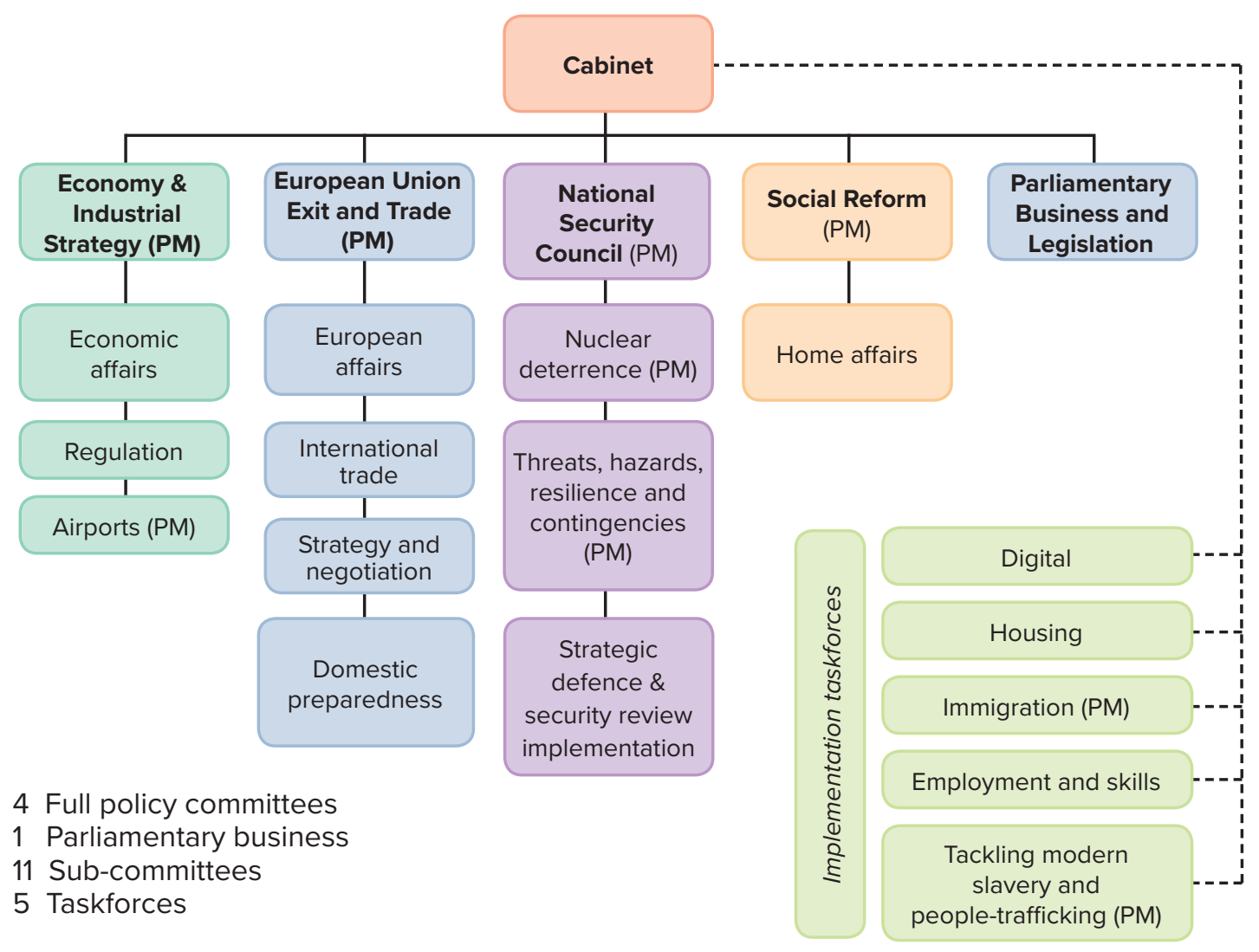

Source: Institute for Government, 2018, redrawn from Figure 1.7

Note: Prime Minister chairs committees marked (PM)

Of course, positional power is not the only kind of power that ministers have, as shown by the low rank at this time for David Davis (in the early days of Brexit one of the most powerful ministers under May). Allen showed that in the 2010-15 coalition government the Liberal Democrats had more positional power in the committee system than they did Cabinet posts (where they had five out of 23). But this positional power was effectively invisible to the public. Voters saw the government as almost exclusively dominated by the Conservatives, because Nick Clegg had naively allowed them to hold the top ('secretary of state') ministerial portfolios in all but one of the major policy departments.

Amongst the several other power bases that matter, ministers control the substantial administrative power of their own department fiefdoms, where they set policy priorities, control key policy-making processes, and shape how a lot of public money is spent. Informal alliances of ministers may have 'blocking power' to delay or frustrate decisions under the 'large majority' rules that prevail in executive decision-making. Other ministers may be politically powerful because they have the Prime Minister's ear. And some Cabinet top ministers can become credible leadership succession candidates, with their own followings in the government party's MPs and perhaps amongst other ministers looking to the future. 


\section{Figure 4: The positional power of Cabinet members in the Cabinet committee system, summer 2016}

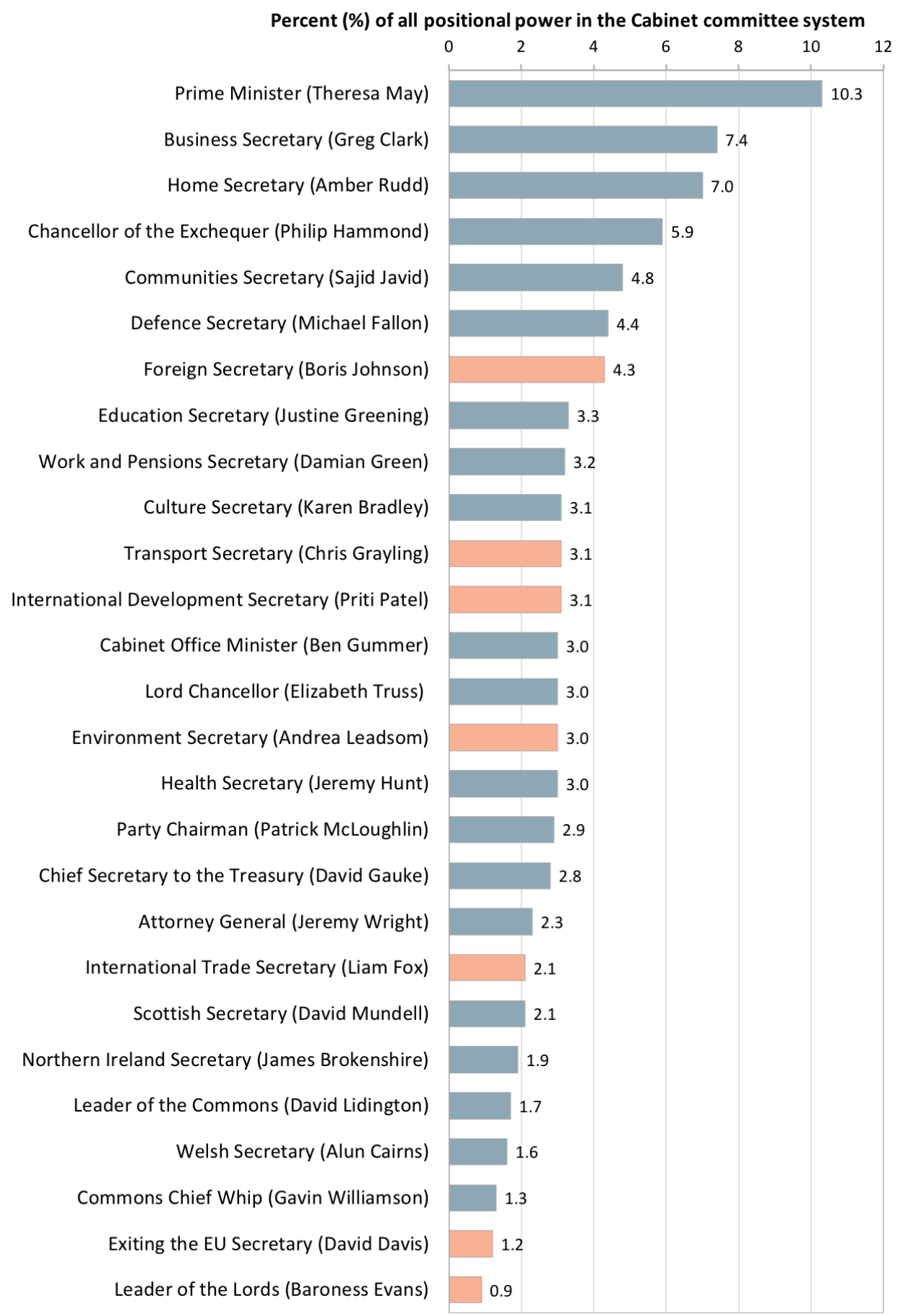

Source: Allen and Siklodi, 2016

Note: Ministers in pink are prominent Brexiteers. 


\section{Budgetary control within government}

The other core co-ordination mechanism is tight Treasury control of public spending, which reached a peak under the Cameron-Clegg governments' austerity programme, maintained for a further year by Cameron after 2015. The budgets for the NHS and overseas aid were maintained in real terms between 2010-16 (although NHS spending fell below the amounts needed for a real standstill budget). But this just meant that the burdens elsewhere, on other domestic, welfare and defence spending, were intensified. An Expenditure Review Group formed from the Treasury and Cabinet Office did a reasonable job, at first, of damage limitation in implementing cutbacks, using a 'do more for less' strategy. David Cameron commented complacently in 2014: 'It must be said, at the time, all manner of horror show predictions were made about what would happen to our country. But what actually happened?'

However, by this time in fact real cuts in programmes, crude 'do less for less' strategies had almost completely taken over, with Whitehall simply passing the need for huge cost cuts down to local authorities, police forces, the armed forces and NHS bodies which could cope only by cutting out services. The costs of such policies only became apparent after lags - for example, big increases in some categories of serious crime followed in 2017-18 after police cutbacks. And in the 2017 general election many voters sent a clear message to Conservative MPs and ministers that public sector pay restraint had to end. A 2018 Theresa May pledge to guarantee long-term NHS real-terms budget increases, and her difficulties with defence spending, both reflected 'incubated' problems resonating with the public. The strategy of 'cutting back until the shoe pinches' by this stage had clearly rising political costs.

The apparatus of Treasury control makes it one of the world's most powerful 'finance ministries'. It 'focuses on managing a number of interrelated systems that taken together provide the basis for spending control in the context of substantial delegation to other actors', according to one study. In preparing three-year spending reviews the Treasury conducts detailed 'bi-lateral' negotiations with spending ministries. It also has a set of macro-controls over budget sectors, which it uses to hold departments to spending totals between reviews, but with some departmental autonomy within agreed totals.

Yet micro budget controls (such as limits on viring unspent monies from one heading to another, and 'clawing back' unspent funding at the year end) also remain. And staff and expertise cuts within the Treasury itself have drastically reduced its understanding of where spending occurs, or why. For example, many government 'blunders' have revolved around IT schemes and big capital investments, for which there are several different but inadequate major project evaluation systems. And UK central government has never yet had any coherent programme for improving government sector productivity.

\section{The 'secret state' within Whitehall}

The UK's still substantial secret state is the last surviving remnant of the British empire's worldwide reach. The main intelligence and security services are:

MI5 (internal security), 
SIS or MI6 (overseas intelligence),

GCHQ (electronic and other tech surveillance),

the Defence Intelligence Staffs (military intelligence).

Their activities are supervised by the Joint Intelligence Committee (JIC) in the Cabinet Office, which coordinates and sanctions major operations, reporting to the Prime Minister. Following the 'dodgy dossier' episode where intelligence was manipulated by the Prime Minister's aides in the lead up to the Iraq war, Whitehall confidence in the quality of information from the four agencies and the Joint Intelligence Committee took several years to rebuild.

The UK is bound into close working relationships with the US intelligence agencies, with SIS linked to the CIA, and GCHQ working hand-in-glove with the US National Security Agency. Less important strong links are to agencies in Australia, Canada and New Zealand, and also to those in a few major European states and EU agencies.

A single Cabinet Office intelligence expenditure vote of $£ 3.1 \mathrm{bn}$ (including $£ 470 \mathrm{~m}$ of capital spending) is declared to Parliament but not further explained in public. Around $£ 85 \mathrm{~m}$ to $£ 100 \mathrm{~m}$ of undeclared intelligence spending is still padded around the Cabinet Office budget, with further amounts in defence. The only parliamentary control over any of this comes from the Intelligence and Security Committee, hand-picked by the Prime Minister from the Commons and Lords. Committee members were previously criticised as 'trusties' but there is now more parliamentary input into their selection (see Chapter 4.3).

The UK also has developed inter-departmental homeland security arrangements which focus on the COBRA meeting (an impressive acronym that actually stands for the mundane 'Cabinet Office, Briefing Room A', where its meetings take place). In principle, the resilience system is also supposed to also cover civil contingencies (such as foot and mouth disease and flooding in the past). But COBRA never met over the 2017 Grenfell Tower disaster, and government co-ordination in the aftermath was very poor.

These highly non-transparent arrangements have fuelled persistent controversy about the existence of an 'inner state', one that controls the drone killings of terror suspects in military action zones overseas, and some extra-legal actions of homeland security or army special forces (which for certain included extra-judicial assassinations in Northern Ireland and perhaps in Afghanistan in earlier periods). The Snowden revelations suggested that GCHQ had done a 'buddy deal' for many years with the NSA to bulk spy on US citizens (which the US agency cannot legally do), in return for the NSA trading back the same information for UK and European citizens (which GCHQ cannot legally do). SIS has been accused of colluding in US renditions and torture of terror suspects implemented by US agencies in Iraq and Afghanistan in 2002-08, using information gained from a rendition programme where prisoners were sent for interrogation to torture-using US-allied states.

Routinely denounced by elite insiders as 'conspiracy theories', these allegations have generally been proved reasonably well-founded. For example, in summer 2018 a report by Parliament's Intelligence and Security Committee found that UK intelligence agencies had tolerated US renditions and derived benefit from CIA tortures of prisoners (for example, submitting questions to people whom they knew were being water-boarded). Arguments for a pattern of 'deep state' cover-ups followed by belated admissions have also gained added 
contextual credence from evidence of policy fiascos perpetrated elsewhere by the UK state such as the police cover-up over mass deaths in 1989 at the Hillsborough football stadium; and the Department of Health's actions over the poisoning of NHS patients over many years with hepatitis B from blood for transfusions imported from the USA.

\section{Policy fiascos and disasters}

Critics have long argued that the UK is unusual in the extent to which it suffers from acute policy disasters and policy fiascos (perfectly foreseeable disasters) - and that the key sources of these problems are the lack of checks and balances in the UK core executive. Majoritarian government, strong Whitehall traditions and a pronounced lack of accountability to the legislature all interact badly with the 'legacy' hangovers of an overstrong executive government tradition using Crown prerogative powers, plus the malign influence of 'new public management' thinking on core civil service competencies (see Chapter 5.3).

Other observers see the UK ministerial elite as being too powerful vis-à-vis their 'generalist' civil servants, able to order that ill-advised policy is implemented. Neither politicians nor their Whitehall advisors are masters of specialist subjects, compounding a long succession of smaller-scale 'blunders'. However, this is arguably an implausibly politically focused analysis, which over-locates responsibility with particular minister and party advisors, neglecting the role of the civil service (see Chapter 5.3) and the specificities of major projects like large-scale IT investments. Ministers may be unrealistic in how they approve schemes like the Universal Credit changes in social welfare, and then may deny and bluster about problems when implementation starts going wrong. Yet all politicians in liberal democracies are policy amateurs, and yet the UK scale of problems is rarely matched in other long-established European democracies.

The risks of unconstrained executive action are especially severe where a Prime Minister and close advisors fall prey to 'groupthink', as May and advisors clearly did in triggering the 2017 early general election. In overseas and defence policy many of the factors above are further compounded by a lingering British empire tradition of foreign and defence policy-making that is elite-dominated, insulated from public opinion and Parliament, and (arguably) lacking in realism. In the spring and early summer of 2018, Theresa May and her Defence Secretary Gavin Williamson were involved in a bitter wrangle over defence budgets. During it the Prime Minister created shock in the 'defence establishment' by questioning whether Britain could any long afford to retain its long-prized goal of being a 'Tier 1' defence power - an 'article of faith' for the defence and foreign policy establishment.

\section{Overseas policy disasters}

In strategic policy-making the most recent policy fiasco was the UK's joint military intervention with France into the civil war in Libya in 2011, aiding the anti-Gaddafi rebels with frequent air strikes, SAS 'advisors' and plentiful arms supplies. Both the intervening countries ran out of bombs and missiles within weeks of the conflict starting, and had to be re-supplied covertly by the USA which nominally was not involved. A lot of Gaddafi regime 
infrastructure was destroyed, and plentiful arms supplies sent to assorted rebel militias. The regime was duly toppled, but Libya descended into near-permanent lower intensity civil war and 'failed state' status. A Commons committee concluded that planning for the aftermath of intervention was minimal and ham-fisted.

As a result, greatly increased flows of refugees began crossing the Mediterranean to reach EU countries, fuelling part of the anti-immigrant momentum that fed into the anxieties of the UK's Brexit voters five years later. And Islamic jihadist forces (such as Isis and al-Qaeda) soon secured toeholds in the Libyan stalemate chaos. The arms initially sent into Libya also spread into all neighbouring countries, reaching Islamic jihadists as far south as Nigeria and Chad. The Libya commitment reflected an over-homogenisation of views by the Prime Minister and colleagues, and an over-confidence (bordering on delusional) about the UK's state capacities in the modern world. Little wonder that Barack Obama publicly described the episode as the 'worst mistake' during his presidency, and in private reputedly called it 'a shit show'.

Amidst these travails, the 2016 official post mortem report into the UK's 2003 joining of the Iraq invasion by Sir John Chilcot's commission (five years in the making and running to 15-million words) was soon lost to view. It painted a bleak picture of how the UK's core executive operated at that time. Blair as Prime Minister and his communication chief (Alastair Campbell) clearly steamrollered military action through the Cabinet and Parliament with false information - a 'dodgy dossier' alleging that Saddam Hussein's Iraq had 'weapons of mass destruction', which in fact did not exist.

\section{Domestic policy disasters}

In terms of domestic policy disasters, the onset of the Brexit referendum in 2016 (discussed above) is perhaps the leading case of the key requirement for the core executive to provide unified control, albeit with checks and balances. The vacuum of leadership that opened up for two weeks or more after Cameron's resignation spoke to this collapse of the core executive's role - as did the Tories' subsequent aborting of the leadership campaign, with all of Theresa May's rivals knocked out or withdrawing.

Two other recent policy crises illuminate different aspects of the limitations on UK core executive operations. First, the onset of the global financial crisis in 2008 , and the forced renationalisation of most UK banks that followed, imposed a decade of acute austerity on UK government, and a considerable burden on taxpayers. These difficulties were made far worse than they might have been by an almost unacknowledged change whereby under Tory and Labour governments the UK state allowed bank liabilities - for which taxpayers were the ultimate guarantor - to expand from early post-war modest levels around half of GDP to a peak just before the crash.

Figure 5 shows that the liabilities of UK financial corporations were almost four times nominal GDP in 1987, and then rose past ten times GDP by 2006, peaking at 11 times GDP just before the GFC broke. Throughout this period, the Treasury, Bank of England and enthusiastic key ministers like Nigel Lawson, Margaret Thatcher and Gordon Brown all fuelled the massive expansion of the UK's finance sector, without imposing any form of 'macro-prudential' regulation of the scale of liabilities the UK state was taking on. Instead 
Figure 5: The financial liabilities of financial corporations in the UK, as a percentage of the country's nominal GDP, from 1987 to 2015

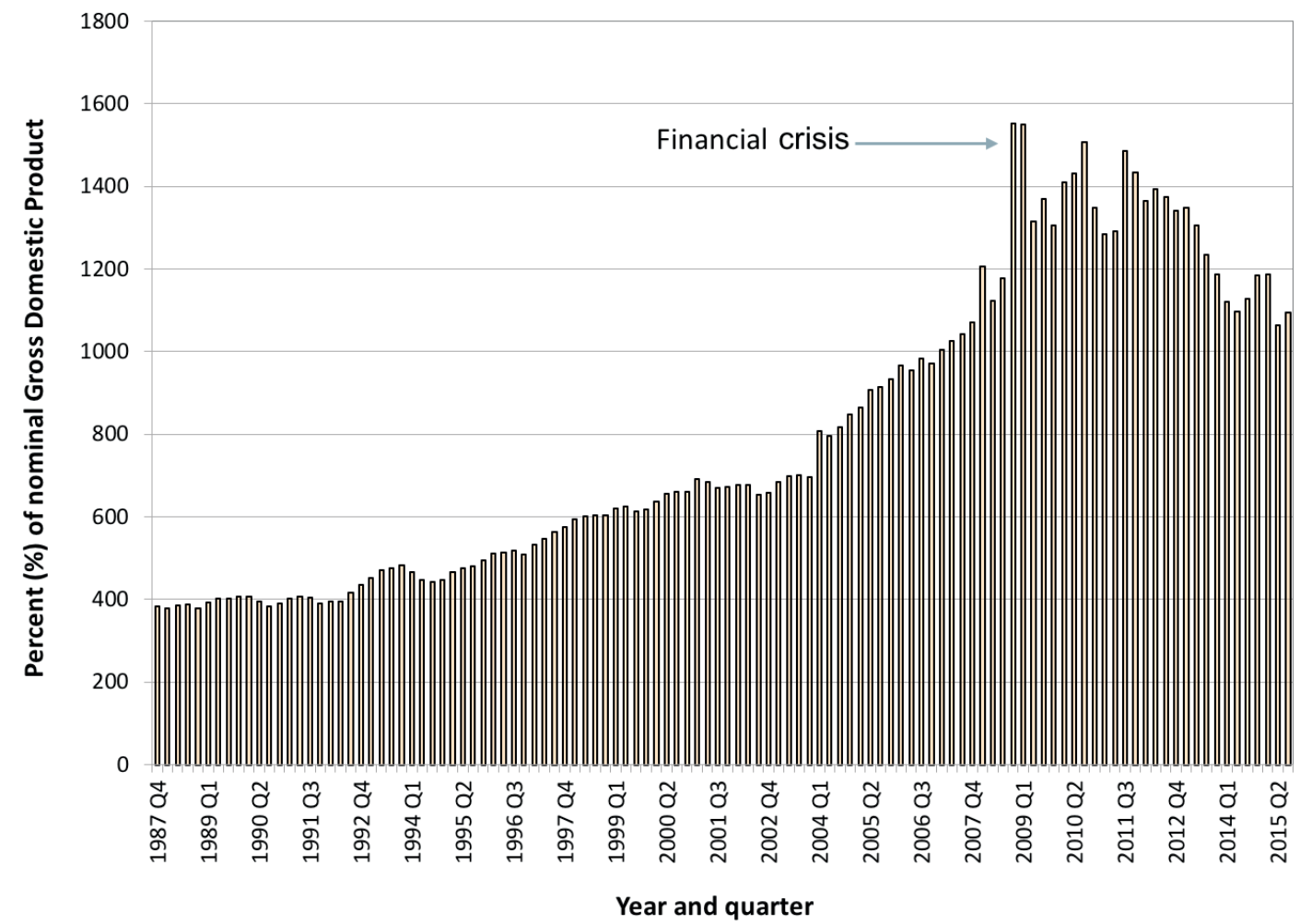

Source: Computed from Office of National Statistics, 2016, Figure 1.

financial de-regulation and 'light touch' regulation were repeatedly pushed by ministers creating an almost completely ineffective apparatus which collapsed precipitately once the crisis struck. In the subsequent recession, financial corporations' liabilities kept on rising, briefly touching levels 15 times GDP in 2009-10 and only plateaued out at 11 times GDP again from around 2014 onwards.

A second example concerns the Grenfell Tower fire in June 2017, when a London tower block was completely devastated by fire in a couple of hours, killing 72 people and injuring hundreds more. The May government ran into immediate trouble, failing to trigger the COBRA emergency committee to manage the disaster, and providing only a woefully inadequate initial state response to the catastrophe. It rapidly emerged that the fire spread so quickly because the block was clad all over in inflammable materials in a disastrously cheapskate refurbishment carried out by the Tory Kensington and Chelsea borough under austerity pressures.

However, by the time that a public inquiry started it became clear that the conditions for the fire had been created by two core executive failures. A long-run campaign to deregulate building safety and foster 'technical innovation' had begun under the Blair and Brown Labour governments and been sustained by the coalition government and Tory 
administrations since 2010. Fire service roles in safety were pared back, regulations were written in incredibly vague and ineffective ways, and building contractors allowed to selfcertify materials and designs. Second, the relevant department (DCLG; Communities and Local Government) was repeatedly warned of cladding fire dangers from 2011 onwards from a succession of incidents, and lobbied by an all-party group of MPs to urgently review regulations. But whereas the Scottish government acted on the same evidence to ban flammable materials in all its high rises, several Tory ministers (plus one Liberal Democrat) at Westminster repeatedly deferred taking any corrective action at all. Add in the incidence of 'public service delivery disasters' (see Chapter 5.3) and the contemporary diversity and significance of UK public policy mistakes is clearly considerable.

\section{Conclusions}

The UK's core executive once worked smoothly. It has clearly degenerated fast in the 21st century. Westminster and Whitehall retain some core strengths, especially a weight of tradition that regularly produces better performance under pressure, reasonably integrated action on homeland security for citizens, and some ability to securely ride out crises. Yet elite conventional wisdoms, which dwelt on a supposed 'Rolls-Royce' machine, are never heard now - after eight years of unprecedented cutbacks in running costs across Whitehall; political mistakes and poor planning over Libya, Afghanistan and Iraq; and the unexpected loss of the Brexit referendum. Now this tarnished record may be capped by the looming threats of either leaving the EU on poor economic terms under a 'hard Brexit' strategy, or of being trapped in an unsatisfactory 'soft' Brexit, where the 'dirty' component of a 'quick and dirty' exit turns into enduring disadvantages.

The clouds in the form of recurring 'policy disasters' and 'fiascos' have also gathered. Both the Conservative and Labour party elites and leaderships, and Whitehall elites themselves, have seemed disinclined to learn the right lessons from past mistakes, or to take steps to foster more transparent, deliberative and well-considered decision-making at the heart of government. Like the Bourbon monarchs, the fear might be that they have 'learnt nothing and forgotten nothing'.

Patrick Dunleavy is Professor of Political Science and Public Policy at the LSE and coDirector of Democratic Audit there. He is also Centenary Professor in the Institute for Governance and Policy Analysis (IGPA), University of Canberra. 